Japan. J. Breed. $41: 325 \sim 329$ (1991)

\title{
Hybrid Cell Lines Produced by Protoplast Fusion between Luffa cylindrica Roem. and Gynostemma pentaphyllum MaKino
}

\author{
Mitsuaki Ito, Hideki Morimoto, Shougo Matsumoto, Kazuhisa Oosumi and Hiroaki Konishi \\ Biochemical Research Institute, Nippon Menard Cosmetic CO.,LTD., 4-66 \\ Asakusa, Ogaki, Gifu, 503
}

\begin{abstract}
Hybrid cell lines were produced by the intergeneric protoplast fusion between Luffa cylindrica Roem. (L. cylindrica) and Gynostemma pentaphyllum MAKINo (G. pentaphyllum). Protoplasts derived from the cotyledons of $L$. cylindrica and protoplasts derived from the cultured cells of $G$. pentaphyllum were fused according to the method of MENCZEL and WOLFE. Four fusion products were confirmed as hybrid cells based on isozyme analysis.

KEY WORDS: Cucurbitaceae, Luffa cylindrica, Gynostemma pentaphyllum, protoplast, fusion
\end{abstract}

\section{Introduction}

The family Cucurbitaceae includes a number of important vegetables, fruit crops and traditional herbs. L. cylindrica have been used as a source of cosmetic material and traditional medicine. G. pentaphyllum have been also used as a traditional herb.

ТАкемото et al. $(1983,1984)$ found that L. cylindrica and $G$. pentaphyllum contained the same saponins as found in Panax ginseng C. A. Meyer.

In this family, there are several reports on the culture of protoplasts and the protoplast fusion (Matsumoto and Takebe 1987, Matsumoto et al. 1987, Tabei et al. 1989, Yamaguchi and Shiga 1989, Oosawa et al. 1989).

This study was conducted to produce hybrid cell lines by the intergeneric protoplast fusion between $L$. cylindrica and G. pentaphyllum.

\section{Materials and Methods}

Cotyledons from the axenic 7 days old seedlings of $L$. cylindrica and cultured cells from the cell suspension of $G$. pentaphyllum were used. The cultured cells were light brown and friable.

The cell suspension of $G$. pentaphyllum have been subcultured at 10 day intervals for more than a year using Murashige and Skoog (MS, 1962) medium supplemented with $0.5 \mathrm{mg} / \mathrm{l}$ picrolam, $0.1 \mathrm{mg} / \mathrm{l}$ kinetin and $0.2 \%$ casamino acid at $25^{\circ} \mathrm{C}$ with $12 \mathrm{hr}$ light (2,000 lux) period.

Cotyledon strips of $L$. cylindrica $(0.5 \mathrm{~g})$ were incubated overnight at $25^{\circ} \mathrm{C}$ in $20 \mathrm{ml}$ of enzyme mixture containing $0.3 \%$ Meicelase (Meiji Seika Kaisha, LTD), $0.05 \%$ Macerozyme R-10 (Yakult Honsha CO., LTD) and 0.4M mannitol, pH 5.5.

To cells $(1 \mathrm{~g})$ of $G$. pentaphyllum harvested 6 days after subculture of the cell suspension was added $20 \mathrm{ml}$ of enzyme mixture containing $1.0 \%$ Cellulase OnozuKA R-10 (Yakult Honsha CO., LTD), $1.0 \%$ Driselase (Kyowa Hakko Kogyo CO., LTD), 0.5\% Macerozyme R-10 and $0.4 \mathrm{M}$ mannitol, $\mathrm{pH}$ 5.5. The mixture was incubated at $25^{\circ} \mathrm{C}$ for $2 \mathrm{hr}$.

Protoplasts of $G$. pentaphyllum were adjusted to a cell density of $2 \times 10^{6}$ cells $/ \mathrm{m} l$.

Received September 17, 1990. 
Protoplasts of $L$. cylindrica were suspended in W5 solution including $10 \mathrm{mM}$ iodoacetoamide (IOA) (Menczel and Wolfe 1984) and incubated at $4{ }^{\circ} \mathrm{C}$ for $10 \mathrm{~min}$. The inactivated protoplasts were then washed twice with W5 solution and adjusted to a density of $2 \times 10^{6}$ cells $/ \mathrm{m} l$.

The IOA-treated protoplasts of $L$. cylindrica and untreated protoplasts of G. pentaphyllum were mixed together in equal volumes and fused according to the method of Menczel and WoLfe (1984).

Fused protoplasts were cultured in the medium for protoplasts of L. cylindrica; modified MS medium (half strength salts) supplemented with $1.0 \mathrm{mg} / \mathrm{l} \alpha$-naphthaleneacetic acid (NAA), $0.5 \mathrm{mg} / \mathrm{l}$ 6-benzyl-aminopurine, $1 \%$ sucrose and $0.3 \mathrm{M}$ mannitol at a cell density of $2 \times 10^{5}$ cells $/ \mathrm{m} l$. After 2 weeks of culture the osmotic pressure of the medium was reduced by adding the same medium supplemented with $0.2 \mathrm{M}$ mannitol.

All cultures were maintained at $25^{\circ} \mathrm{C}$ with $12 \mathrm{hr}$ light $(2,000$ lux $)$ period.

Hybridity of the cell lines was determined by glucose-6-phosphate dehydrogenase (GDH) analysis utilizing native polyacrylamide gel electrophoresis ( $1 \mathrm{~mm}$ thick gels, $7.5 \%$ acrylamide). Gels were stained for GDH activity according to a modified method of SING and BrewER (1968).

Chromosome number was observed microscopically according to the flame drying method of Kurata and Omura (1978).

\section{Results and Discussion}

In this intergeneric fusion between protoplasts derived from cotyledon of L. cylindrica (Fig. 1A) and those from cultured cells of G. pentaphyllum (Fig. 1B), about 15 percent of the surviving population were fusants. After the fusion treatment, heterokaryons (Fig. 1C) had a green part from L. cylindrica and a colourless part from G. pentaphyllum. The heterokaryons started cell division 5 days after protoplast culture. IOA-treated protoplasts derived from cotyledon of L. cylindrica and untreated protoplasts derived from cultured cells of $G$. pentaphyllum did not devide in the used medium at all.

After 6 weeks of culture, small colonies $(0.5-1 \mathrm{~mm}$ diameter) were recovered. They were cultured on the agar medium for another a month. Finally 6 small calli were obtained.

These calli were named $\mathrm{CF} 1, \mathrm{CF} 2, \mathrm{CF} 3, \mathrm{CF} 4, \mathrm{CF} 5$ and $\mathrm{CF} 6$, respectively. $\mathrm{CF} 3, \mathrm{CF} 4$ and CF6 were yellow friable calli, and CF5 was a white friable callus.

However, the $\mathrm{CF} 1$ and $\mathrm{CF} 2$ were green compact calli, which looked alike those derived from protoplasts of L. cylindrica cotyledon. This morphological characteristic corresponded with the result of GDH isozyme analysis (Fig. 2). Varied isozyme changes of hybrid cells and gradual chromosome elimination of one parent had been reported (KAO 1977, WeTter 1977). In this study, it could be considered that the CF1 and CF2 gradually lost chromosomes of G. pentaphyllum after protoplast fusion.

Four calli (CF3, CF4, CF5, CF6) after 3 months of culture were confirmed as hybrid cells since they possessed parental homodimeric isozymes in $\mathrm{GDH}$ isozyme analysis (Fig. 2).

These calli had parental characteristics for phytohormone sensitivity, too.

L. cylindrica had a chromosome number $2 \mathrm{n}=26$ (Fig. 3A). G. pentaphyllum had a chromo- 
A

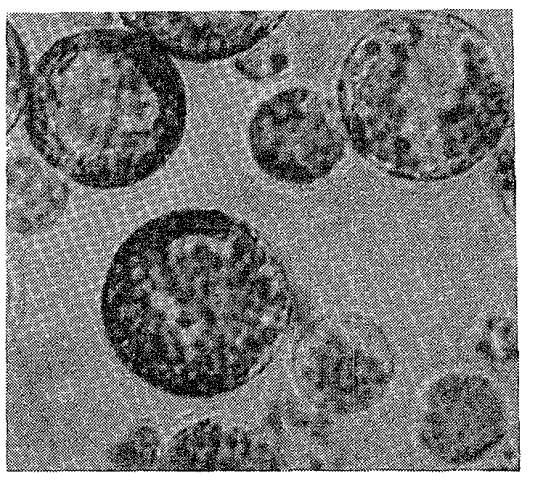

B

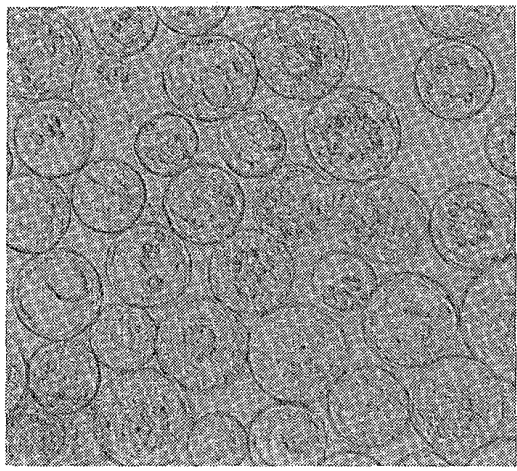

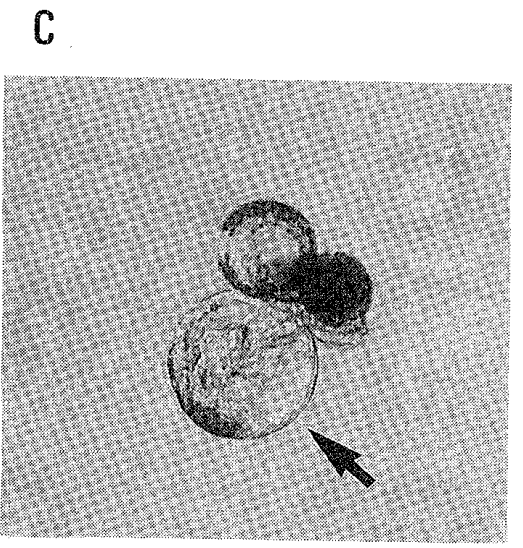

Fig. 1. Protoplast fusion.

A : Protoplasts derived from cotyledon of $L$. cylindrica

B : Protoplasts derived from cultured cells of $G$. pentaphyllum

C : Heterokaryon (indicated by an arrow)

some number $2 \mathrm{n}=66$ (Fig. 3B). Almost all of cultured cells of $G$. pentaphyllum were composed of tetraploid (Fig. 3C), but some of them were aneuploids.

Chromosomes of the hybrid cells after 3 months of culture were investigated (Fig. 3D-G). Those hybrid cells had different chromosome numbers and were more than $158(26+132)$.

The varied chromosome numbers of the hybrid cells might have derived from varied chromosome numbers of the cultures cells of $G$. pentaphyllum.

These four hybrid calli have been maintained by subculturing in MS medium supplemented with $1.0 \mathrm{mg} / \mathrm{l}$ NAA (or $3.0 \mathrm{mg} / \mathrm{l}$ IAA), $0.5 \mathrm{mg} / l$ kinetin and $0.2 \%$ casamino acid for 2 years.

These hybrid calli after 2 years of culture also possessed the parental homodimeric isozymes in GDH isozyme analysis (data not shown). The stabillity of their chromosome number could not be still confirmed since it was too many to count their chromosomes. 


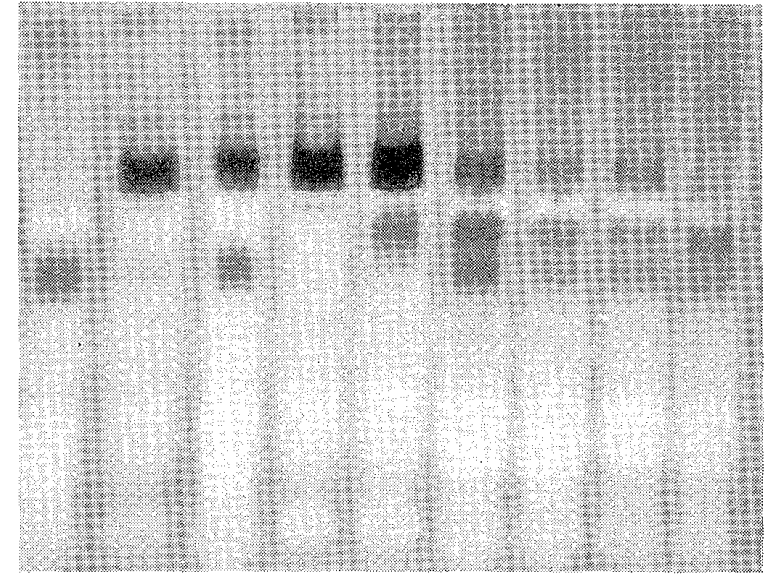

G L Mix CF1 CF2 CF3 CF4 CF5 CF6

No shoot or root has been regenerated from these hybrid calli.

It was confirmed that these hybrid calli contained a saponin qualitatively. Therefore, we will try to analize the contents of a saponin.

In conclusion, we produced hybrid cell lines by protoplast fusion between $L$. cylindrica and G. pentaphyllum. These cell lines would be useful materials for the study of the cucurbitaceae-breeding and saponin biosynthesis.

Fig. 2. Isozyme analysis of glucose-6-phosphate dehydrogenase.

$\mathrm{G}$ : Cultured cell of $G$. pentaphyllum

$\mathrm{L}$ : Callus derived from protoplasts of $L$. cylindrica cotyledon

Mix : $\mathrm{G}+\mathrm{L}$

CF1-CF6 : Fusion products

A

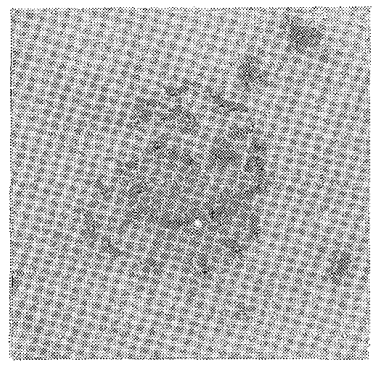

B

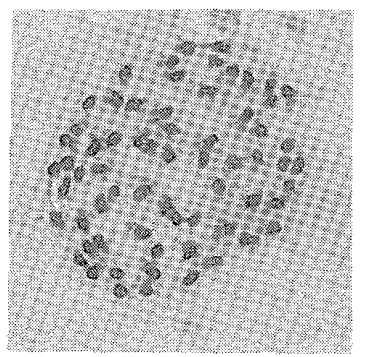

$\mathbb{C}$

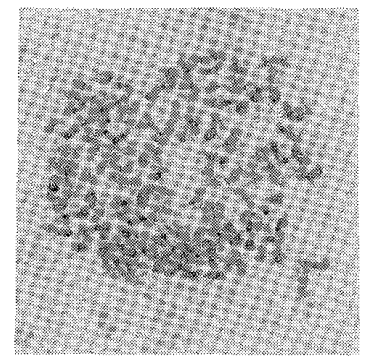

D

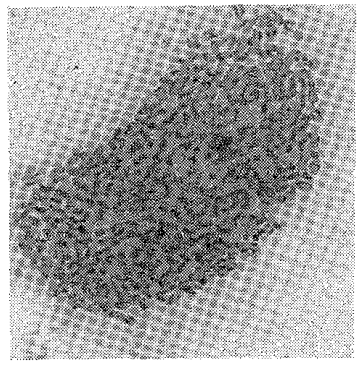

E

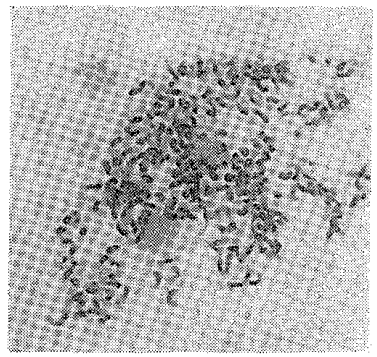

F

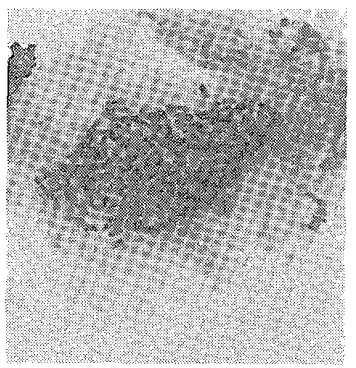

G

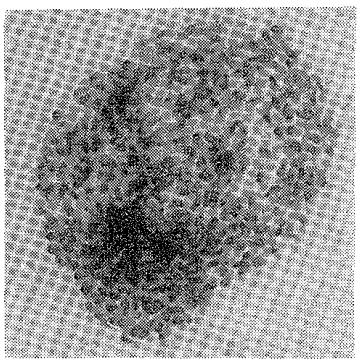

Fig. 3. Chromosomes of L. cylindrica, G. pentaphyllum and hybrid cells.

A : Root tip of L. cylindrica

B : Root tip of $G$. pentaphyllum

C : Tetraploidal cultured cell of $G$. pentaphyllum

D : CF3 E : CF4 F : CF5 G : CF6 


\title{
Literature Cited
}

KaO, K. N. 1977. Chromosomal behavior in somatic hybrids of soybean-Nicotiana glauca. Molec. gen. Genet. $150: 225 \sim 230$

Kurata, N. and T. Omura 1978. Karyotype analysis in rice. 1. A new method for identifying all chromosome pairs. Jpn. J. Genet. 53 (4) : $251 \sim 255$

Matsumoto, S. and I. TAKebe 1987. Callus formation and root differentiation by cotyledon protoplasts of melon (Cucumis melo L.). Plant Tissue Cult. Lett. 4 (1) : 18 21

$\longrightarrow$, M. ITo, H. Konishi and I. TAKeBE 1987. Isolation and culture of protoplasts from Luffa cylindrica suspension culture. Plant Tissue Cult. Lett. 4 (1) : 35 37

Menczel, L. and K. Wolfe 1984. High frequency of fusion induced in freely suspended protoplast mixtures by polyethylene glycol and dimethylsulfoxide at high pH. Plant Cell Reports 3:196 198

Murashige, T. and F. Skoog 1962. A revised medium for rapid growth and bioassays with tobacco tissue culture. Physiol. Plant 15:473 497

Oosawa, E., K. Yoshioka, Y. Nomura, Y. Asano and K. OOSawa 1989. Plant regeneration from hypocotyl protoplast of melon. Jpn. J. Breed. 39 (S2) : 24 25

SING, C. F. and G. J. BREWER 1969. Isozymes of a polyploid series of wheat. Genetics $61: 391 \sim 398$

TABeI, Y., T. Kanno, I. Igarashi and T. Nishio 1987. Plant regeneration from cotyledon protoplast of melon (Cucumis melo L.). Abstr. Japan. Soc. Hort. Sci. Autumn Meet. : 236 237

Takemoto, T., S. Arihara, T. Nakajima and M. Okuhira 1983. Studies on the constituents of Gynostemma pentaphyllum MAKINo. I. Structures of gypenoside I-XIV. Yakugaku Zasshi 103 (2) : $173 \sim 185$

$\longrightarrow$, K. Yoshizawa, K. Kusumoto, I. Yano and T. Hayashi 1984. Studies on the constituents of Cucurbitaceae plants. VI. On the saponin constituents of Luffa cylindrica RoEM.(1). Yakugaku Zasshi 104 (3) : 246 255

Yamaguchi, J. and T. Shiga 1989. Plant regeneration by protoplast fusion of Cucumis melo L. between Cucurbita maxima X C. moschata. Jpn. J. Breed. 39 (S1) : 28 29

WeTteR, L. R. 1977. Isozyme patterns in soybean-Nicotiana somatic hybrid cell lines. Molec. gen. Genet. $150: 231 \sim 235$

\author{
ウリ科植物へチマとアマチャヅルの細胞融合による雑種細胞の作出 \\ 伊藤三明・森本秀樹・松本省吾・大隅和寿・小西宏明 \\ （日本メナード化粧品，大垣市，广503）
}

\footnotetext{
へチマ, Luffa cylindrica ROEM. とアマチャヅル，Gynostemma pentaphyllum MAKIKO の体細胞融合を行い， その雑種細胞を作出した。すなわち, $10 \mathrm{mM}$ のヨードアセトアミド処理で不活化したへチマの子葉プロトプラスト と末処理のアマチャヅルの培養細胞プロトプラストをPEG-DMSO 法で融合した．染種細胞のみを選拔するため に，未処理のへチマの子葉プロトプラストがコロニ一形成し，かつ，未処理のアマチャヅルの培養細胞プロトプラ ストが分裂できない培地を用いて培峑した，その結果，6個の小カルスを得ることができ，韦のうち，4個の小カル スが培養開始後 3 ケ月目のアイソザイム分析において両親のバンドを共有し雑種性を示した(Fig. 2). これらの雑種 カルスのうち, 3 個は黄色の柔らかいカルスであり, 残りの1個は白色の桑らかいカルスであった。これらの雑種力 ルスは培養開始後 2 年目のアイソザイム分析に㧍いても両親のバンドを共有していた。雑種性を示さなかった 2 個 の小カルスは緑色の硬いカルスで，形態的にもアイソザイム分析に挍いてもへチマ子葉プロトプラスト由来のカル スとよく似ていた，雑種カルスは，ホルモン要求性においても両親の性質を併世持っていた。これらの雑種カルス の染色体数は非常に多く，また，それぞれ異なっていた（Fig.3）。この多㥞性は，アマチャヅル培養細胞における 染色体数の多様性に依存しているのではないかと思われる。これらの雑種カルスは根や植物体を再生しなかったが, 定性的にサポニン合成を確認することができた。
} 